\title{
Influence of Sowing Time and Varieties on Growth and Yield of Horsegram (Macrotyloma uniflorum Lam.) under Rainfed Condition
}

\author{
K. Ramani $^{1^{*}}$, K. R. Latha ${ }^{1}$, N. Tamilselvan ${ }^{2}$ and R. Sivakumar ${ }^{3}$ \\ ${ }^{1}$ Department of Agronomy, Tamil Nadu Agricultural University, Coimbatore, India \\ ${ }^{2}$ Sugarcane Research Station, Sirugamani, India \\ ${ }^{3}$ Crop physiology, Tamil Nadu Agricultural University, Regional Research Station, \\ Paiyur, India \\ *Corresponding author
}

\section{A B S T R A C T}

\section{Keywords}

Horsegram, Time of sowing, Varieties, Growth characters, Yield attributes, Yield

\section{Article Info}

Accepted: 17 October 2020 Available Online: 10 November 2020
A field investigation was conducted at Regional Research Station, Tamil Nadu Agricultural University, Paiyur, Tamil Nadu during rainy season (October 2019 to February 2020) to find out the best sowing time and suitable variety in horsegram. The trial was carried out strip plot design with three replications. Strip one consisted of five dates of sowing viz., $\mathrm{D}_{1}-40^{\text {th }}$ meteorological standard week (MSW), $\mathrm{D}_{2}-41^{\mathrm{st}} \mathrm{MSW}, \mathrm{D}_{3}-$ $42^{\text {nd }}$ MSW, $D_{4}-43^{\text {rd }}$ MSW and $D_{5}-44^{\text {th }}$ MSW and; strip two comprised of four varieties viz., $\mathrm{V}_{1}$ - Paiyur $1, \mathrm{~V}_{2}$ - Paiyur $2, \mathrm{~V}_{3}-$ CRIDA $18 \mathrm{R}$ and $\mathrm{V}_{4}$ - Indira Kulthi-1. The experiment was carried out under rainfed condition using north east monsoon rains. Results of the field investigation revealed that higher growth parameters such as plant height and drymatter production and yield of haulm were recorded in horsegram varieties sown during $40^{\text {th }} \mathrm{MSW}\left(\mathrm{D}_{1}\right)$ than other sowing dates, however higher yield attributes such as number of pods plant ${ }^{-1}$, number of seeds pod $^{-1}, 100$ grain weight and grain yield were noted when horsegram was sown during $41^{\text {st }} \mathrm{MSW}\left(\mathrm{D}_{2}\right)$ compared to other time of sowing. Among the varieties under study, Paiyur 2 variety recorded higher drymatter production, number of pods plant ${ }^{-1}$, number of seeds pod $^{-1}, 100$ grain weight, grain yield and haulm yield than other varieties. Hence, it can be concluded that Paiyur 2 variety sown during $40^{\text {th }}$ MSW produced more growth and $41^{\text {st }}$ MSW recorded more yield characters; and yield of horsegram under rainfed condition of north-western agro-climatic zone of Tamil Nadu.

\section{Introduction}

Horsegram (Macrotyloma uniflorum Lam.) is a short day plant and hardy crop. It is mainly sown in rainy season by poor farmers in tribal localities and drought-prone areas of India. It is used to improve the soil fertility and highly nutritious grain legume species. It can be used as forage and green manure crop in many tropical zones. In many parts of India, especially in south India, it is traditionally cultivated as a cover crop and considered to be a suitable crop for intercropping with cereals and millets viz., pearl millet, finger millet, little millet and maize (Krishna, 2010). 
Horsegram is exclusively cultivated in Karnataka, Andhra Pradesh, Odisha, Tamil Nadu, Madhya Pradesh, Chhattisgarh, Bihar, West Bengal and Jharkhand, and also in foothills of Uttaranchal and Himachal Pradesh in India. In India, it covers an area of about 4.00 lakh hectares with 2.47 lakh tonnes production during 2017-18 (Anonymous, 2018).

Growth and yield parameters are influenced by environmental factors (Rainfall, temperature, humidity and wind) varieties, seed rate, spacing and time of sowing (Sofield et al., 1977). Horsegram is grown in subhumid to semi-arid climate with an annual rainfall of 300-600 mm (Krishna, 2010).

Most of the farmers are growing local varieties for a long time. These varieties are low yielding, late and non-synchronous in maturity and susceptible to yellow mosaic virus. Therefore, a variety with high yield, proper response to fertilizers with superior performance under multiple seasons in low rainfall conditions is the need of the hour. In Tamil Nadu, Paiyur 1 and Paiyur 2 are the predominant varieties. A brown seeded horsegram variety CRIDA 18R was developed by CRIDA and released by Central Varietal Release Committee (CVRC) in 2009 for South India (Maruthi et al., 2018). Indira Kulthi-1 is a horsegram variety released from Chhattisgarh. These two varieties are better performing in many parts of country and are to be tested for their performance in the predominantly horsegram grown zone (Northwestern zone) of Tamil Nadu.

Time of sowing and the crop environmental factors decide the seed development, drymatter production, flowering, seed set and maturity period of the crop because crop growth is mainly an interaction between environmental factors and genetic material (Tahir et al., 2009). Of which, the time of sowing is an important and crucial factor affecting the growth and yield of the crop under rainfed condition. However, there is no specified time of sowing identified for horsegram though the crop is predominantly sown between September and November. With this background, the field experimentation was made to study the different sowing times and two varieties evolved out-side the state in comparison with the ruling Paiyur 1 and Paiyur 2 varieties under rainfed condition utilizing the north east monsoon rainfall.

\section{Materials and Methods}

The field experiment was conducted in Regional Research Station, Tamil Nadu Agricultural University, Paiyur, Krishnagiri District. The experiment site comes under north western zone of Tamil Nadu. It is geographically located at a latitude of $12^{\circ} 21^{\text {, }}$ $\mathrm{N}$, longitude of $78^{\circ} 18^{\prime} \mathrm{E}$ and altitude of $490 \mathrm{~m}$ above mean sea level (MSL). The weekly mean minimum and maximum temperature of the cropping period (from 4.10.2019 19.02.2020) was $20.54^{\circ} \mathrm{C}$ and $31.22^{\circ} \mathrm{C}$, respectively. Total rainfall received during the crop period was $304.7 \mathrm{~mm}$ with 20 rainy days.

The soil of experimental field was clay loam in texture. The experiment was laid out in strip plot design with three replications. Strip one consisted of five time of sowing viz., $\mathrm{D}_{1}$ : $40^{\text {th }}$ meteorological standard week (MSW) $\left(1^{\text {st }}\right.$ Oct $-7^{\text {th }}$ Oct), $\mathrm{D}_{2}: 41^{\text {st }} \mathrm{MSW}\left(8^{\text {th }}\right.$ Oct $-14^{\text {th }}$ Oct), $\mathrm{D}_{3}: 42^{\text {nd }} \mathrm{MSW}\left(15^{\text {th }}\right.$ Oct $-21^{\text {st }}$ Oct $), \mathrm{D}_{4}$ : $43^{\text {rd }}$ MSW $\left(22^{\text {nd }}\right.$ Oct $-28^{\text {th }}$ Oct $), D_{5}: 44^{\text {th }}$ MSW $\left(29^{\text {th }}\right.$ Oct $-4^{\text {th }}$ Nov $)$ and the strip two was with four varieties, such as $\mathrm{V}_{1}$ : Paiyur 1 , $\mathrm{V}_{2}$ : Paiyur 2, $\mathrm{V}_{3}$ : CRIDA18R and $\mathrm{V}_{4}$ : IndiraKulthi-1.

The field was ploughed three times thoroughly with tractor drawn cultivator and 
brought to fine tilth. Good quality seeds were sown at recommended spacing $(30 \times 10 \mathrm{~cm})$. Recommended dose of fertilizer 12.5:25:12.5 $\mathrm{kg}$ of NPK ha ${ }^{-1}$ was applied in the form of urea $(46 \% \mathrm{~N}), \mathrm{SSP}\left(16 \% \mathrm{P}_{2} \mathrm{O}_{5}\right)$ and muriate of potash $\left(60 \% \mathrm{~K}_{2} \mathrm{O}\right)$ uniformly as basal dose prior to sowing. Thinning was done on 10 days after sowing (DAS) leaving a healthy seedling. One hand weeding was done after 25 DAS of every sowing with the help of manual labour. Powdery mildew occurred at the time of vegetative stage was controlled by spraying with Mancozeb@2g lit ${ }^{-1}$ of water and yellow mosaic virus at reproductive stage was controlled by spraying Neem oil $30 \mathrm{ml} \mathrm{lit}^{-1}$ of water. Foliar spray was taken up with $0.5 \%$ $\mathrm{FeSO}_{4}$ to rectify the iron chlorosis. All other package of practices were made as per CPG (2012).

Data were collected on the growth characters, viz., plant height $(\mathrm{cm})$ and drymatter production (kg/ha); yield attributes such as number of pods plant ${ }^{-1}$, number of seeds pod $^{-1}$ and test weight (100 grains weight) $(\mathrm{g})$; grain yield ( $\mathrm{kg} / \mathrm{ha}$ ) and haulm yield ( $\mathrm{kg} / \mathrm{ha})$ using standard procedure. Harvesting of whole plant was done from each net plot area, border rows, and sample rows separately. Harvested pods were separated, dried, threshed, cleaned and manually weighed at $12 \%$ moisture level and recorded as grain yield in $\mathrm{kg} \mathrm{ha}^{-1}$. The left out haulms after threshing the grains were weighed separately for each plot and values were noted in $\mathrm{kg} \mathrm{ha}^{-1}$. The recorded data were subjected to statistical analysis (Gomez and Gomez, 1984).

\section{Results and Discussion}

\section{Effect of sowing dates on growth and yield parameters and yield of horsegram}

Sowing dates had significant effect on growth characters, yield attributes and yield of horsegram except test weight (100 grain weight)
(Table 1, 2 and 3). Among the sowing dates, the plants sown at $\left(\mathrm{D}_{1}\right) 40^{\text {th }} \mathrm{MSW}(1 \mathrm{Oct}-7 \mathrm{Oct})$ significantly recorded taller plants $(102.2 \mathrm{~cm})$ and higher drymatter production $(3253 \mathrm{~kg} / \mathrm{ha})$ compared to $\mathrm{D}_{2}$ due to uneven distribution of rainfall. Optimum amount of rainfall in more rainy days created congenial conditions for increased growth characters in the initial stages and later stages received optimum growing conditions for obtaining higher growth $\left(D_{1}\right)$ whereas uneven distribution of rainfall i.e., higher rainfall in less number of rainy days $\left(D_{2}\right)$ or less rainfall in more no. of rainy days $\left(D_{3}\right.$, $\left.\mathrm{D}_{4}, \mathrm{D}_{5}\right)$ caused significantly lesser growth characters. Lower plant height $(66.6 \mathrm{~cm})$ and drymatter production $(1584 \mathrm{~kg} / \mathrm{ha})$ were recorded in plants sown on $44^{\text {th }} \mathrm{MSW}$ (29 Oct 4 Nov) $\left(D_{5}\right)$. Maximum growth characters observed on $40^{\text {th }}$ standard week might be due to increase in amount of rainfall and more number of rainy days (Fig. 1). Similar results were observed by (Rehman et al., 2009) and (Sikdar et al., 2015). Significantly higher number of pods plant ${ }^{-1}$ (51.6) and number of seeds pod $^{-1}$ (5.9) were recorded in plants sown on $41^{\text {st }}$ MSW (8 Oct - 14 Oct) which might be due to less rainfall during flowering i.e., $49^{\text {th }} \mathrm{MSW}$ (Fig. 1) that increased flower number and high rainfall caused reduced flower number in $D_{2}$ with same no. of rainy days. Test weight was statistically found to be non-significant for all sowing dates taken into consideration. Among the different sowing dates, $\mathrm{D}_{2}$ recorded higher test weight $(3.46 \mathrm{~g})$. The highest grain (833 $\mathrm{kg} / \mathrm{ha}$ ) recorded $\mathrm{D}_{2}$ and haulm (2091 kg/ha) yield were recorded with $\mathrm{D}_{1}$. Data revealed that sowing done at $44^{\text {th }} \mathrm{MSW}\left(\mathrm{D}_{5}\right)$ recorded the lowest yield of grain and haulm. The early sowing $\left(\mathrm{D}_{2}\right)$ resulted in better development of grains than delayed sowing $\left(\mathrm{D}_{5}\right)$ (ZakeerHussain, 1989). This might be due to better environmental conditions during critical stages under rainfed conditions for growth and development of horsegram. Similar results were reported by (Kripanidhi et al., 2017) in horsegram. 
Table.1 Effect of sowing time and varieties on growth parameters of horsegram

\begin{tabular}{|c|c|c|c|c|c|c|}
\hline \multicolumn{7}{|c|}{ Plant height (cm) } \\
\hline Treatments & $\begin{array}{c}D_{1^{-}} \\
40^{\text {th }} \text { MSW }\end{array}$ & $\begin{array}{c}D_{2^{-}} \\
4^{\text {st }} \text { MSW }\end{array}$ & $\begin{array}{c}D_{3^{-}} \\
42^{\text {nd }} M S W\end{array}$ & $\begin{array}{c}D_{4}- \\
43^{\text {rd }} \text { MSW }\end{array}$ & $\begin{array}{c}D_{5^{-}} \\
44^{\text {th }} \text { MSW }\end{array}$ & Mean \\
\hline$V_{1}$-Paiyur 1 & 105.8 & 96.9 & 78.5 & 76.7 & 75.1 & 86.6 \\
\hline $\mathrm{V}_{2-}$ Paiyur 2 & 111.6 & 99.7 & 86.8 & 74.1 & 67.9 & 88.0 \\
\hline $\mathrm{V}_{3}-$ CRIDA 18R & 108.5 & 92.8 & 105.4 & 72.3 & 62.1 & 88.2 \\
\hline $\mathrm{V}_{4}$ - Indira Kulthi - 1 & 82.7 & 76.4 & 72.8 & 62.6 & 61.4 & 71.2 \\
\hline Mean & 102.2 & 91.5 & 85.9 & 71.4 & 66.6 & 83.5 \\
\hline & D & $\mathbf{V}$ & D at $\mathrm{V}$ & & & \\
\hline S.Ed. & 3.4 & 2.9 & 6.6 & & & \\
\hline C.D. $(P=0.05)$ & 7.9 & 7.2 & 15.9 & & & \\
\hline $\mathbf{F}$ & $*$ & $*$ & $*$ & & & \\
\hline \multicolumn{7}{|c|}{ Dry matter production (kg/ha) } \\
\hline Treatments & $\begin{array}{c}D_{1}- \\
40^{\text {th }} \text { MSW }\end{array}$ & $\begin{array}{c}D_{2}- \\
41^{\text {st }} M S W\end{array}$ & $\begin{array}{c}D_{3}- \\
4^{\text {nd }} \text { MSW }\end{array}$ & $\begin{array}{c}D_{4^{-}} \\
\mathbf{4 3}^{\text {rd }} \text { MSW }^{-1}\end{array}$ & $\begin{array}{c}D_{5}^{-} \\
44^{\text {th }} \text { MSW }\end{array}$ & Mean \\
\hline$V_{1}$-Paiyur 1 & 3298 & 3306 & 2577 & 2397 & 1587 & 2633 \\
\hline$V_{2-}$ Paiyur 2 & 3458 & 3244 & 3206 & 2983 & 1790 & 2936 \\
\hline $\mathrm{V}_{3}-\mathrm{CRIDA} 18 \mathrm{R}$ & 3167 & 3013 & 2401 & 2644 & 1508 & 2547 \\
\hline $\mathrm{V}_{4}$ - Indira Kulthi - 1 & 3090 & 2761 & 2344 & 2265 & 1450 & 2382 \\
\hline \multirow[t]{2}{*}{ Mean } & 3253 & 3081 & 2632 & 2572 & 1584 & 2624 \\
\hline & D & $\mathbf{V}$ & D at $\mathbf{V}$ & & & \\
\hline S.Ed. & 99.2 & 78.4 & 181.4 & & & \\
\hline C.D. $(P=0.05)$ & 228.8 & 191.8 & 433.8 & & & \\
\hline $\mathbf{F}$ & $*$ & $*$ & NS & & & \\
\hline
\end{tabular}

Fig.1 Weather parameters during cropping period (2019 - 2020)

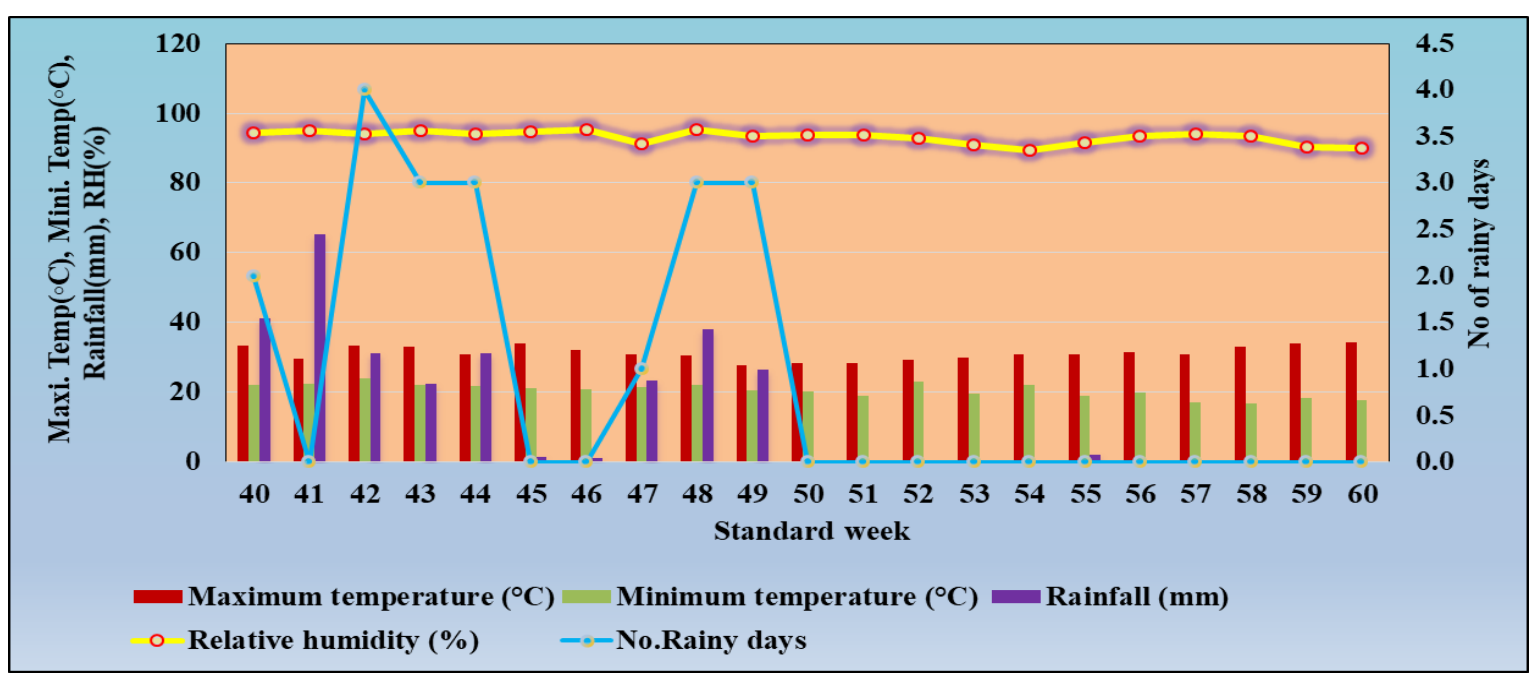


Table.2 Effect of sowing time and varieties on yield parameters of horsegram

\begin{tabular}{|c|c|c|c|c|c|c|}
\hline \multicolumn{7}{|c|}{ No. of pods per plant } \\
\hline Treatments & $\begin{array}{c}D_{1^{-}} \\
40^{\text {th }} \text { MSW }\end{array}$ & $\begin{array}{c}D_{2^{-}} \\
41^{\text {st }} M S W\end{array}$ & $\begin{array}{c}D_{3^{-}} \\
42^{\text {nd }} M S W\end{array}$ & $\underset{43^{\mathrm{rd}} \text { MSW }}{D_{4}}$ & $\begin{array}{c}D_{5^{-}} \\
44^{\text {th }} M S W\end{array}$ & Mean \\
\hline$V_{1}$-Paiyur 1 & 53.0 & 52.0 & 37.7 & 36.3 & 22.0 & 40.2 \\
\hline $\mathrm{V}_{2}$-Paiyur 2 & 50.0 & 56.7 & 49.7 & 45.0 & 24.0 & 45.1 \\
\hline V $_{3-}$ CRIDA 18R & 46.7 & 49.3 & 37.7 & 39.3 & 20.3 & 38.7 \\
\hline $\mathrm{V}_{4}$ - Indira Kulthi - 1 & 40.3 & 48.3 & 36.0 & 35.7 & 17.7 & 35.6 \\
\hline \multirow[t]{2}{*}{ Mean } & 47.5 & 51.6 & 40.3 & 39.1 & 21.0 & 39.9 \\
\hline & D & $\mathbf{V}$ & $D$ at $\mathrm{V}$ & & & \\
\hline S.Ed. & 1.2 & 1.1 & 2.4 & & & \\
\hline C.D. $(P=0.05)$ & 2.7 & 2.6 & 5.8 & & & \\
\hline $\mathbf{F}$ & $*$ & $*$ & NS & & & \\
\hline \multicolumn{7}{|c|}{ No. of seeds per pod } \\
\hline Treatments & $\begin{array}{c}D_{1^{-}} \\
40^{\text {th }} \\
M S W\end{array}$ & $\begin{array}{c}D_{2^{-}} \\
41^{\text {st }} \mathrm{MSW}\end{array}$ & $\begin{array}{c}D_{3^{-}} \\
42^{\text {nd }} M S W\end{array}$ & $\begin{array}{c}D_{4}- \\
43^{\text {rd }} \text { MSW }\end{array}$ & $\begin{array}{c}D_{5^{-}} \\
44^{\text {th }} \text { MSW }\end{array}$ & Mean \\
\hline $\mathrm{V}_{1}$-Paiyur 1 & 6.7 & 6.3 & 5.7 & 5.0 & 4.0 & 5.5 \\
\hline $\mathrm{V}_{2}$-Paiyur 2 & 6.0 & 7.0 & 6.0 & 5.7 & 4.3 & 5.8 \\
\hline V $_{3-}$ CRIDA 18R & 5.0 & 5.3 & 5.3 & 5.3 & 3.7 & 4.9 \\
\hline $\mathrm{V}_{4}$ - Indira Kulthi - 1 & 4.7 & 5.0 & 4.3 & 4.0 & 3.3 & 4.3 \\
\hline \multirow[t]{2}{*}{ Mean } & 5.6 & 5.9 & 5.3 & 5.0 & 3.8 & 5.1 \\
\hline & D & $\mathbf{V}$ & D at V & & & \\
\hline S.Ed. & 0.17 & 0.17 & 0.38 & & & \\
\hline C.D. $(P=0.05)$ & 0.40 & 0.43 & 0.91 & & & \\
\hline $\mathbf{F}$ & $*$ & $*$ & NS & & & \\
\hline \multicolumn{7}{|c|}{ Test weight(g) } \\
\hline Treatments & $\begin{array}{c}D_{1^{-}} \\
40^{\text {th }} \mathrm{MSW}\end{array}$ & $\begin{array}{c}D_{2-} \\
41^{\text {st }} \text { MSW }\end{array}$ & $\begin{array}{c}D_{3^{-}} \\
42^{\text {nd }} M S W\end{array}$ & $\begin{array}{c}D_{4}- \\
4^{\text {rd }} \text { MSW }\end{array}$ & $\begin{array}{c}D_{5^{-}} \\
44^{\text {th }} \text { MSW }\end{array}$ & Mean \\
\hline V $_{1}$-Paiyur 1 & 3.42 & 3.46 & 3.40 & 3.38 & 3.31 & 3.39 \\
\hline$V_{2}$ Paiyur 2 & 3.52 & 3.64 & 3.54 & 3.48 & 3.40 & 3.52 \\
\hline$V_{3^{-}}$CRIDA $18 R$ & 3.44 & 3.45 & 3.44 & 3.43 & 3.28 & 3.41 \\
\hline $\mathrm{V}_{4}$ - Indira Kulthi - 1 & 3.20 & 3.28 & 3.18 & 3.04 & 2.80 & 3.10 \\
\hline \multirow[t]{2}{*}{ Mean } & 3.39 & 3.46 & 3.39 & 3.33 & 3.20 & 3.35 \\
\hline & D & $\mathbf{V}$ & $D$ at $V$ & & & \\
\hline S.Ed. & 0.12 & 0.11 & 0.25 & & & \\
\hline C.D. $(P=0.05)$ & 0.27 & 0.28 & 0.60 & & & \\
\hline $\mathbf{F}$ & NS & $*$ & NS & & & \\
\hline
\end{tabular}


Table.3 Effect of sowing time and varieties on yield of horsegram varieties

\begin{tabular}{|c|c|c|c|c|c|c|}
\hline \multicolumn{7}{|c|}{ Grain yield (kg/ha) } \\
\hline Treatments & $\begin{array}{c}D_{1^{-}} \\
40^{\text {th }} \text { MSW }\end{array}$ & $\begin{array}{c}D_{2^{-}} \\
41^{\text {st }} \mathrm{MSW}\end{array}$ & $\begin{array}{c}D_{3^{-}} \\
4^{\text {nd }}{ }^{-} \text {MSW }\end{array}$ & $\begin{array}{c}D_{4}- \\
43^{\text {rd }} \text { MSW }\end{array}$ & $\begin{array}{c}D_{5^{-}} \\
44^{\text {th }} \text { MSW }\end{array}$ & Mean \\
\hline$V_{1^{-}}$Paiyur 1 & 863 & 833 & 659 & 613 & 418 & 677 \\
\hline $\mathrm{V}_{2^{-}}$Paiyur 2 & 824 & 900 & 820 & 763 & 450 & 751 \\
\hline$V_{3^{-}}$CRIDA 18R & 771 & 810 & 614 & 677 & 378 & 650 \\
\hline $\mathrm{V}_{4}$ - Indira Kulthi - 1 & 706 & 791 & 610 & 569 & 374 & 610 \\
\hline Mean & 791 & 833 & 676 & 655 & 405 & 672 \\
\hline & D & $\mathbf{V}$ & D at $\mathrm{V}$ & & & \\
\hline S.Ed. & 26.5 & 27.3 & 59.1 & & & \\
\hline C.D. $(P=0.05)$ & 61.2 & 66.8 & 142.4 & & & \\
\hline $\mathbf{F}$ & $*$ & $*$ & $*$ & & & \\
\hline \multicolumn{7}{|c|}{ Haulm yield(kg/ha) } \\
\hline Treatments & $\begin{array}{c}D_{1^{-}} \\
40^{\text {th }} \text { MSW }\end{array}$ & $\begin{array}{c}D_{2^{-}} \\
\mathbf{4 1}^{\text {st }} \mathbf{M S W}\end{array}$ & $\begin{array}{c}D_{3^{-}} \\
42^{\text {nd }} M^{-}\end{array}$ & $\begin{array}{c}\mathrm{D}_{4}- \\
4^{\text {rd }}{ }^{-}\end{array}$ & $\begin{array}{c}D_{5^{-}} \\
44^{\text {th }} \text { MSW }\end{array}$ & Mean \\
\hline$V_{1}$-Paiyur 1 & 2088 & 2166 & 1654 & 1538 & 1049 & 1699 \\
\hline $\mathrm{V}_{2}$-Paiyur 2 & 2259 & 2067 & 2058 & 1915 & 1129 & 1886 \\
\hline$V_{3^{-}}$CRIDA 18R & 2033 & 1934 & 1541 & 1696 & 948 & 1630 \\
\hline $\mathrm{V}_{4^{-}}$Indira Kulthi - 1 & 1983 & 1772 & 1531 & 1426 & 934 & 1529 \\
\hline \multirow[t]{2}{*}{ Mean } & 2091 & 1985 & 1696 & 1644 & 1015 & 1686 \\
\hline & D & $\mathbf{V}$ & D at V & & & \\
\hline S.Ed. & 52.2 & 73.7 & 151.9 & & & \\
\hline C.D. $(P=0.05)$ & 120.4 & 180.3 & 368.1 & & & \\
\hline $\mathbf{F}$ & $*$ & $*$ & $*$ & & & \\
\hline
\end{tabular}

Note: * - Significant, NS - Non Significant, MSW - Meteorological Standard Week

\begin{tabular}{|l|l|}
\hline D: Date of sowing (Strip1) & V: Varieties (Strip2) \\
\hline $\mathbf{D}_{1}: 40^{\text {th }}$ MSW $(1$ Oct -7 Oct $)$ & $\mathrm{V}_{1}:$ Paiyur 1 \\
\hline $\mathbf{D}_{2}: 41^{\text {st }}$ MSW $(8$ Oct -14 Oct $)$ & $\mathrm{V}_{2}:$ Paiyur2 \\
\hline $\mathbf{D}_{3}: 42^{\text {nd }}$ MSW $(15$ Oct -21 Oct $)$ & $\mathrm{V}_{3}:$ CRIDA 18R \\
\hline $\mathbf{D}_{4}: 43^{\text {rd }}$ MSW $(22$ Oct -28 Oct) & $\mathrm{V}_{4}:$ Indira Kulthi-1 \\
\hline $\mathbf{D}_{5}: 44^{\text {th }}$ MSW $(29$ Oct -4 Nov $)$ & \\
\hline
\end{tabular}

Effect of varieties on growth and yield parameters and yield of horsegram

The genetic diversity in different varieties showed varying response on growth, yield attributes and yield of horsegram. The results revealed that plant height, total biomass, number of pods plant ${ }^{-1}$, number of seeds $\operatorname{pod}^{-1}$, test weight, and yield were significant among the varieties tested (Table 1,2 and 3).
Taller plants were recorded in CRIDA 18R $\left(\mathrm{V}_{3}\right)(88.2 \mathrm{~cm})$ and shorter plants were observed in Indira Kulthi-1 $\left(\mathrm{V}_{4}\right)(71.2 \mathrm{~cm})$ variety. Paiyur $2\left(\mathrm{~V}_{2}\right)$ showed significant superiority in total dry matter accumulation (2936 kg/ha) compared to other varieties. The lowest dry matter was accumulated in Indira Kulthi-1 $\left(\mathrm{V}_{4}\right) \quad(2382 \mathrm{~kg} / \mathrm{ha})$. The growth characters were significantly affected by varieties grown under rainfed condition 
(Table 1). The results are in accordance with (Maruthi et al., 2018). Paiyur $2\left(\mathrm{~V}_{2}\right)$ produced maximum number of pods plant ${ }^{-1}$ (45.1) which was followed by Paiyur $1\left(\mathrm{~V}_{1}\right)$ (40.2), CRIDA 18R ( $\left.\mathrm{V}_{3}\right)$ (38.7) and Indira Kulthi-1 $\left(V_{4}\right)$ (35.6), respectively. Similar trend was followed in number of seeds $\operatorname{pod}^{-1}$. Differences in yield components might be attributed to their genetic variability. These results were similar to the results reported by (Reddy et al., 2015) and (Panotra et al., 2016). 100 grain weight was higher in Paiyur $2(3.52 \mathrm{~g})$ followed by CRIDA 18R (3.41g), Paiyur 1 (3.39 g) and Indira Kulthi-1 (3.10g). Similar results were reported by (Rehman et al., 2009) and (Sikdar et al., 2015). The grain (751 kg/ha) and haulm yield (1886 kg/ha) were significantly higher in Paiyur $2\left(\mathrm{~V}_{2}\right)$ variety. Higher yield in Paiyur 2 variety might be due to overall advantage of increased growth attributes, yield attributes, physiological parameters and favourable meteorological parameters compared to other varieties under rainfed condition. The results are in accordance with (Kripanidhi et al., 2017) and (Sikdar et al., 2015).

Interaction of sowing dates and varieties on growth and yield parameters and yield of horsegram

Interaction between sowing dates and varieties were found significant in plant height, grain yield and haulm yield of horsegram. The interaction effect was found to be statistically non-significant on remaining other growth and yield parameters. The Paiyur 2 variety $\left(\mathrm{V}_{2}\right)$ sown at $40^{\text {th }} \mathrm{MSW}$ (1 Oct -7 Oct) $\left(\mathrm{D}_{1}\right)$ found to be superior among other sowing dates and varieties and recorded maximum growth characters viz., plant height $(111.6 \mathrm{~cm})$ and dry matter production $(3458 \mathrm{~kg} / \mathrm{ha})$, yet Paiyur 2 variety $\left(\mathrm{V}_{2}\right)$ sown during $41^{\text {st }} \mathrm{MSW}(8 \mathrm{Oct}-14 \mathrm{Oct})$ $\left(\mathrm{D}_{2}\right)$ showed maximum yield attributes viz., number of pods plant $^{-1}$ (56.7), number of seeds $\operatorname{pod}^{-1}(7.0)$ and test weight (3.64 g); grain yield $(900 \mathrm{~kg} / \mathrm{ha})$. This might be due to favourable agro-meteorological condition existed during the cropping period of Paiyur 2 variety and late maturation character of that variety compared to other varieties. The maximum temperature, minimum temperature and rainfall were found favourable for better vegetative growth. The number of rainy days and amount of rainfall were higher during vegetative crop growth and found to be least at flowering and maturation phases of Paiyur 2 horsegram variety. The long duration nature of Paiyur 2 variety facilitated the receipt of more amount of rainfall $(263.5 \mathrm{~mm}$ in 18 rainy days) which in turn supported proper growth, biomass accumulation, seed filling rate and grain weight. Hence the interaction recorded higher yield.

In conclusion the date of sowing plays a dynamic role in producing optimum yields and reduce the yield loss. The results clearly indicated the influence of sowing dates, varieties and their interaction effect on the yield of rainfed horse gram. Hence, it can be concluded that $41^{\text {st }} \mathrm{MSW}$ recorded maximum yield due to higher amount of rainfall in vegetative stage and lesser amount of rainfall during flowering and maturity stages which increased number of pods per plant and hence the grain yield. Paiyur 2 variety sown during $41^{\text {st }}$ MSW produced more yield characters; and yield of horse gram under rainfed condition of north-western agro-climatic zone of Tamil Nadu. Though $40^{\text {th }}$ MSW recorded higher growth parameters, except Paiyur 1 the yield parameters and yield were higher in $41^{\text {st }}$ MSW sown crops irrespective of varieties.

\section{References}

Anonymous, (2018). Area, Production, and yield of principle crops, Directorate of Economics and statistics, Department of Agriculture an Cooperation report, 
Government of India, New Delhi, available on www.indiastat.com

Gomez, K. A., and Gomez, A. A. (1984). Statistical procedures for agricultural research: John Wiley and Sons.

Kripanidhi, R., Devendra, S.,and Jat, A. (2017). Effect of sowing time and seed rate on growth and yield of chickpea cultivars. Advance Research Journal of Crop Improvement, 8(1), 1-16.

Krishna, K. R. (2010). Agroecosystems of South India: nutrient dynamics, ecology and productivity: UniversalPublishers.

Maruthi, V., Reddy, P. R., Reddy, K., Reddy, B., and Saroja, D. (2018). Agronomic management of CRIDA-18R-a new variety of horsegram (Macrotyloma uniflorum) for South India matching monsoon patterns of rainfall. Legume Research-An International Journal, 41(1), 102-107.

Panotra, N., Kumar, A., and Singh, O. (2016). Effect of varieties and dates of sowing on growth parameters, yield attributes and yield of blackgram (Vigna mungo L.). International Journal of Science, Environment and Technology, 5(6), 3821-3826.

Reddy, G. K., Reddy, P. M., Kumari, P. L., and Krishna, T. G. (2015). Response of pigeonpea varieties to time of sowing during rabi season. IOSR
Journal of Agriculture and Veterinary Science, 8(2), 12-15.

Rehman, A., Khalil, S., Nigar, S., Rehman, S., Haq, I., Akhtar, S., Khan, A., and Shah, S. (2009). Phenology, plant height and yield of mungbean varieties in response to planting date. Sarhad $J$. Agric, 25(2), 147-151.

Sikdar, S., Abuyusuf, M., Ahmed, S., and Tazmin, M. (2015). Variety and Sowing Time on the Growth and yield of Chickpea (Cicerarietinum L.) in Souther Region of Bangladesh.

Sofield, I., Evans, L., Cook, M., and Wardlaw, I. F. (1977). Factors influencing the rate and duration of grain filling in wheat. Functional Plant Biology, 4(5), 785-797.

Tahir, M., Ali, A., Nadeem, M. A., Hussain, A., and Khalid, F. (2009). Effect of different sowing dates on growth and yield of wheat (Triticum aestivum L.) varieties in district Jhang, Pakistan. Pakistan journal of life and social sciences, 7(1), 66-69.

Zakeer Hussain, M. (1989) Physiological analysis of the effect of sowing dates on phenology growth an yield of horsegram (Macrotyloma uniflorus medik) cultivars. Acharya NG Ranga Agricultural University, Rajendranagar, Hyderabad.

\section{How to cite this article:}

Ramani, K., K. R. Latha, N. Tamilselvan and Sivakumar, R. 2020. Influence of Sowing Time and Varieties on Growth and Yield of Horsegram (Macrotyloma uniflorum Lam.) under Rainfed Condition. Int.J.Curr.Microbiol.App.Sci. 9(11): 2214-2221. doi: https://doi.org/10.20546/ijcmas.2020.911.265 